\title{
Te Kotahitanga: The Effective Teaching Profile and its Impact on Māori Student Achievement
}

\author{
Gayathri Prabhakar Pillai
}

\begin{abstract}
Te Kotahitanga is a Kaupapa Māori research and development programme that aims at improving Māori student achievement. Through interviews with students, teachers and whānau, the characteristics of teachers who made a difference were identified. These characteristics were drawn together to form the Effective Teaching Profile (ETP). This literature review provides a brief background on the Te Kotahitanga programme with an emphasis on the ETP, and it impact on Māori students' achievement in secondary schools. The educational disparities that exist and perpetuate for indigenous (Māori) learners in Aotearoa/New Zealand are discussed as a rationale for implementing Te Kotahitanga in schools. This literature review explores the principles of the ETP and how these impact on Māori achievement. The ETP is also considered from a Resource Teacher: Learning and Behaviour (RTLB) viewpoint.
\end{abstract}

Keywords: Māori, student achievement, Te Kotahitanga

\section{Research Paper}

\section{INTRODUCTION}

The Te Kotahitanga project needs no introduction to secondary school teachers around Aotearoa/ New Zealand. The project was developed and implemented from 2001 by the Mãori Research Institute at the School of Education at the University of Waikato, and was funded by the Ministry of Education from that time until 2013. The success and sustainability of the programme has been discussed in detail over the years. There is a great deal of literature available on the topic of educational achievement of indigenous students in schools all over the world. Since Te Kotahitanga is an Aotearoa/New Zealand programme, mainly Aotearoa/New Zealand studies have been used because of their particular relevance to Māori students in this country.

\section{Educational disparity in Aotearoa? New Zealand Schools}

One of the major challenges in the Aotearoa/New
Zealand education system is the social and economic disparity between the indigenous Mãori and the dominant non-Māori (Pākehā)people. According to Bishop, Berryman, Wearmouth and Peter (2012), Māori have higher levels of unemployment and incarceration and are at higher risk of physical illness, poverty and educational underachievement. These disparities are reflected in all levels across the education sector. Many policies, projects and programmes have been developed and implemented for reducing the educational disparities between Mãori and Pākehā over the years, but the disparities continue.

Although the Treaty of Waitangi promised power sharing and self-determination for both Māori and Pākehā, the relationships between these two groups were politically, socially and economically dominated by Pākehā which led to the marginalisation of Māori people (Bishop \& Glynn, 1999). According to Bishop and Glynn, indigenous languages, values, beliefs and practices have not been represented in Aotearoa/New Zealand classrooms. This has led to the state playing a major role in destroying Māori language and culture, replacing them with the culture of the colonisers.

Earlier studies by Ladson-Billings (1995) and Sheurich and Young (1997) indicated that where schools practise 'majority' pedagogical methods that are at odds with the cultural pedagogical methods of the minority culture, institutional racism ensues. Berryman and Glynn (2004) found that such practices were very commonplace in Aotearoa/New Zealand and a generation of Māori people neither learned to speak the Māori language nor have an insight into their traditions and cultural practices. These findings reiterate what Vygotsky (1978) and McNaughton (1995) pointed out; that the sociocultural perspectives on human learning emphasise the importance of the responsive social and cultural context in which learning takes place as major factors to successful learning.

\section{Programmes aimed at Māori education prior to Te Kotahitanga}

The development of the Taha Māori programme 
was one of the earliest attempts to bring cultural integrity into schools. The programme was initiated in the 1980s in response to the growing need among Māori and non-Māori educators to recognise and acknowledge Māori as the tangata whenua (first people) of Aotearoa/New Zealand (Bishop \& Glynn, 2004). Te Kohanga Reo (preschool Māori language nests), Kura Kaupapa Māori (Māori medium primary schools), Wharekura (Māori-medium secondary schools) through to Whare Wānanga (Māori medium tertiary institutions) are all initiatives based on Kaupapa Māori as the underlying philosophy (Smith, 1995). According to Smith (1992), Kaupapa Māori is "the philosophy and practice of being and acting Māori"(p.63). Kaupapa Māori adopts a more culturally-appropriate approach and it underpins the philosophy and motivation within a range of Māoridriven schooling and education initiatives.

In the Kaupapa Māori settings, Māori values and practices are used to facilitate teaching and learning. Core values such as manaakitanga (caring; supporting), aroha (compassion; respect) and whakaiti (humility) are at the core of all interactions. Tuakana (an elder/more capable learner) support the learning of teina (a younger/less capable learner), and this learning pedagogy is incorporated into a wider pedagogical framework that deems learning to be a reciprocal process; learners care for and facilitate the learning of their peers (Smith, 1995).

Just as Kaupapa Māori settings provide guidelines for what constitutes excellence in Māori education and connects with Māori aspirations, mainstream schools needed a philosophical framework or approach which would enable Māori learners to reach their potential in a bicultural context. That is seen as essential for the development of education relations and interactions which will increase educational achievement and reduce disparities (Bishop et al., 2006). Bishop (2005) suggests that locating solutions within Māori cultural ways of knowing actually offers workable solutions to educational achievement and disparities. This reality has seen a push to create new metaphoric spaces in which Māori feel safe to bring their own prior knowledge and experiences to mainstream educational contexts in order to support their learning (Bishop \& Berryman, 2012). Ultimately, Te Kotahitanga offers a Kaupapa Māori response to the dominant Pākehā discourse which in bygone years has marginalised Māori potential and cultural aspirations (Bishop, 1996).

Te Kotahitanga commenced in 2001 by gathering a number of narratives of experiences of secondary school students in five mainstream secondary schools (Bishop, 1996). These narratives were complimented by the shared stories of parents, principals and teachers.
The rest of the project is developed based on these stories. The students in their stories identified the main influences on their educational achievement as inclass relationships and interactions between Māori students and teachers (Bishop, Berryman, Tiakiwai \& Richardson, 2003).

In contrast, the majority of teachers suggested that the major influences on educational achievement of Māori are the children themselves, whānau circumstances or structural issues. Bishop, Berryman, Tiakiwai and Richardson (2003) point out that this deficit theorising by teachers is the major reason behind Māori underachievement. The study also showed that when teachers were provided with professional development which places them in non-confrontational situations, they could critically reflect on their theorising and how it impacts on Māori student achievement. Agentic (being an active agent), non-deficit theorising is evidenced in teachers developing caring classroom relationships and interactions. Many international studies which focus on improving indigenous student achievement support the relevance of transforming teaching practices and the school culture that recognise indigenous students cultural values and experiences (Sarra, 2011). According to Bishop (2008), in Aotearoa/New Zealand, Te Kotahitanga seeks to promote an educational system where power is shared between self-determining individuals within non-dominating relations of interdependence, where learning is interactive, culture is valued, and participants are connected and committed to one another.

Based on the observations and the narratives of the students, Bishop, et al. (2003) developed an effective teaching profile (ETP) that rejects deficit theorising about Māori student achievements. The students raised concern about the majority of teaching practices in relation to themselves as Māori students. They provided possible solutions to improve teaching practices that would help them to engage more effectively with learning in the classroom (Bishop et al., 2003). These solutions were categorised into different characteristics of the ETP. The student suggestions were then aligned with current literature on effective teaching. The findings of two previous studies, viz Te Toi Huarewa (Bishop, Berryman \& Richardson, 2001) and AIMHI (Hawk \& Hill, 2000) were used in creating the ETP. The ETP promoted agentic discursive positioning and the implementation of caring and learning relationships in the classroom (Bishop \& Berryman, 2012). ETP forms the basis of the Te Kotahitanga professional development programme that has covered 49 schools across the country in four phases (Bishop, Berryman, Wearmouth, Peter \& Clapham, 2011). 


\section{Part 1 and 2 of the Effective Teaching Profile}

The ETP is made up of two parts. The first part identifies two major understandings that effective teachers of Māori have and the second part identifies six ways that effective teachers relate and interact with Māori students on a daily basis (Bishop \& Berryman, 2009). The first of the two understandings is teachers vehemently reject deficit theorising as a means of explaining Māori students' educational achievement levels. Bishop and Berryman (2009) explain that if we think of other people having defects, it affects the way we think about them, and the relations and interactions we have with them could be negative and unproductive. If the students think that we, as teachers, have thoughts that are deficient, they will react negatively. These findings are supported by researchers such as Alton-Lee (2003) and McLaren (2003). Positive, agentic thinking of the teacher is fundamental in creating learning contexts where young Māori students are able to be themselves as Māori, where students can care for and learn from each other, where Māori students' own self-determination is fundamental to classroom relations and interactions (Bishop \& Berryman, 2009).

Part Two discusses how effective teachers' actions bring about changes in Māori students educational achievement. The six ways in which teachers relate and interact with Māori students are described as manaakitanga (caring for the person), mana motuhake (caring for performance), ngā turanga takitahi ne ngā mana whakahaere (creating a well-managed learning setting), wānanga (effective teacher interaction), ako (strategies) and kotahitanga (outcomes) (Bishop et al., 2003). In practice this means that teachers care and acknowledge the mana of the students as culturally-located individuals. Teachers will have high expectations of students and will be able to manage their classroom to promote learning. This creates whānau-type relations and interactions within the classroom and between teachers, students and their homes. All these, together with the discursive teaching interactions and strategies, and a focus on a formative assessment process, forms the second part of ETP (Bishop \& Berryman, 2009).

Bishop et al. (2012) observed that fundamental to the ETP is teachers' understanding of the need to reject deficit theorising and taking an agentic position in their theorising about their practice. In order to change the teaching practices, a professional development programme was introduced. It provided teachers with professional learning opportunities where they could critically evaluate where they discursively positioned themselves when forming their own images, principles and practices with regards to Māori and other minority groups in class
(Bishop et al., 2003). Teachers were given ongoing opportunities to consider the implications of their discursive positioning on their own agencies and for Māori students' learning (Bishop et al., 2012). Bishop and Berryman (2009) point out that teachers collaboratively promote, monitor, and reflect upon students' learning outcomes so as to modify their instructional practices in ways that will lead to improvements in Māori student achievement.

However, there were teachers who questioned the implications of the Te Kotahitanga model of teacher positioning. Gutschlag (2007) argues that there is actually a large gap between deficit theorising and agency which is already populated by a number of alternatives to these two discursive positions. Gutschlag observes that deficit theorising has been used to create a scenario in which agentic positioning is the only reasonable position available for teachers to take and thus the teachers are left without a choice. It is strongly recommended that alternative positions should be opened up for debate before Te Kotahitanga's critical potential can be realised (Gutschlag, 2007).

In contrast to this, Lawrence (2011) agrees that as a non-Māori teacher she had applied Te Kotahitanga principles and she has done this by facilitating a process of critical self- reflection on her discursive positioning as a teacher and the way in which it helped to build up interactions and relationships with Māori students. Lawrence (2011) understands that there is no list of strategies which one should stick to and that a teacher should be a learner working from a relational base to develop a culturally-responsive pedagogy of relations.

\section{Implications of ETP on Māori achievement}

The analysis of implementing the ETP proves that schools which implemented it effectively saw Māori student schooling experiences improve significantly. In addition, participation, engagement, retention and achievement all showed positive gains in relation to the comparison group of schools (Bishop et al., 2012; Meyer et al., 2010). Evidence from the Te Kotahitanga project (Bishop et al., 2007) and from a three year evaluation of the project (Meyer et al., 2010) showed that facilitators have helped most of the (75 percent) teachers to incorporate ETP in such a way that they are now able to engage students in teaching for understanding. The evidence demonstrated that the implementation of pedagogical intervention was successful. Māori students in these intervention schools made greater gains than Māori students in non-intervention schools. However, Bishop et al. (2012) raise concerns whether these gains can be sustained in the intervention schools and whether they can be scalable in both existing and new schools. 
It is clear from the analysis of the data from Phase 3 that Māori student achievement patterns continued to improve in association with the maintenance of changes in teacher's practices (Bishop et al., 2011; Meyer et al., 2010). The data analysis of Phase 3 categorises schools (12 of them) into four categories: high implementers and high maintainers of the project (four schools); previously high implementers but currently low maintainers (three schools), previously partial implementers but currently poised to implement fully (four schools), and low implementers and low maintainers (one school).

Schools which are high implementers and high maintainers managed to embed the project into their systems, policies and processes. Such schools kept their facilitators in permanent positions although the funding had ceased for them (Bishop, et al., 2012). There is strong evidence that these school leaders have taken the theories and principles of Te Kotahitanga as their own, especially the understanding about strong relationships between the quality of teachers theorising and practice with Māori student outcomes. In the second category are schools that implemented the Te Kotahitanga project at the initial stages but allowed the professional development cycle to be eroded in the latter stages due to problems of providing ongoing support for facilitators and funding problems. The current staff are committed to implement ETP into their classrooms but there are limited opportunities for the induction of new staff into the programme (Meyer et al., 2010).

Schools in the third category are schools which experienced implementation and maintenance problems such as changes in leadership, strong resistance from middle managers, problems with funding, competition between bilingual units and mainstream classes, and competition for resources from other projects. These problems affected the proper implementation of the Effective Teaching Profile through the professional development cycle (Bishop et al., 2012). However, there were individuals who showed excellence and subject departments which fully-implemented the principles of this project. There were leaders in these schools who were willing to spend their own funding for the maintenance of the project (Bishop et al., 2012). The only school in the fourth category faced problems in implementing and maintaining it. This school has opted for alternative approaches to Māori student achievement.

Bishop et al. (2011) found that the sample size of the groups is small and suggests that further research is needed with a greater range of student outcome measures. Because of this, it may be difficult to draw solid conclusions; however there is evidence that Māori students in the seven schools in the first two categories are making better progress than those in the latter two categories (Bishop et al., 2011). The teachers from the first two categories are effective implementers of the ETP in their classrooms and they have reported steady gains in Māori student attendance, retention, engagement and achievement (Bishop \& Berryman, 2009). While comparing the NCEA results in these first two categories, it was found that in 2006, 2008 and 2009 the mean percentage of Māori students' who gained NCEA Level 1 was significantly higher in the high implementers, high maintainers category than previously high implementers, currently low maintainers schools. Overall, the pedagogic intervention has been effective in reducing the educational disparities and improving the retention and schooling experiences of Māori students in the first large group of schools (Bishop et al., 2012).

Using a theory or principle-based model designed for the purpose of evaluation, the 12 schools in the third phase were examined in their sixth and seventh years since the beginning of the programme. The findings of this research showed that schools varied in their degree of project implementation and maintenance and this range was associated with a range of student outcomes. Those who had been the most effective implementers of the intervention have seen the greatest gains made by the Māori students in NCEA Level 1. In his sabbatical research report, Taffs (2012) mentions that in his school the NCEA Level 1 achievement was 43 percent in 2005 and this had gone up to 76 percent in 2010 among Māori boys.

\section{Effective teaching profile in the RTLB context}

The RTLB Toolkit lists seven guiding principles for RTLB practice. One of these is 'culturally-responsive practices' which means recognising, valuing and responding to the needs of Māori. It incorporates the competencies within Tātaiako: Cultural Competencies for Teachers of Māori Learners (Ministry of Education, 2011), such as wānanga (participating with learners and communities), whanaungatanga (actively engaging in respectful working relations with Māori learners and their families), manaakitanga (showing integrity, sincerity and respect to Māori beliefs, culture and language), tangata whenuatanga (affirming Māori learners as Māori) and ako (taking responsibility for their own learning and that of Mãori learners). This aligns with the core principles of ETP. A culturally-responsive approach ensures that RTLB develop relationships with Māori whānau and community members so that they can actively participate in the decision-making process to improve Māori achievement (RTLB Toolkit). Bishop and Berryman (2009) reiterate that fundamental to the ETP is the creation of culturally-responsive contexts for 
learning for Māori students which clearly agrees with the principles of the RTLB Toolkit.

In her keynote address at the Te Kotahitanga conference in 2010, Berryman described how Te Kotahitanga professional development included RTLBs in the ETP training in certain schools as a part of team-building. Although there is no direct mention of how Te Kotahitanga is used in RTLB practices, it is clear that the ideas, principles and values of both practices overlap (Berryman, 2010).

\section{CONCLUSION}

The evidence suggests that the changes in teacher understandings and behaviours contribute to changes in their relationships and interactions with Māori students. The teachers who implemented ETP showed greater caring, improved classroom management and changed their classroom interactions from traditional to discursive, and spent more time on actual learning (Bishop et al., 2012). They also found that Māori students became more academicallyengaged, completed more work in class, attended class regularly, and saw their summative assessment results improved (Bishop et al., 2006).

Even though there is strong evidence that highlights constructive ways to improve Māori achievement through the implementation of ETP, the question is how to sustain these gains. Full implementation of the ETP in mainstream schools and its sustainability is reliant on the commitment and advocacy of school management and leadership. While the government supported the programme during the initial stages, the funding stopped from 2013 and schools were left with the choice of using their own money to fund the continued professional development associated with this programme. In 2013, the Ministry of Education initiated a new programme "Building on Success", which combines the best of Te Kotahitanga, Starpath, He Kākano and Te Whare Wānanga o Awanuiārangi in response to raising Māori student achievement. Hopefully this programme will deliver a more integrated "package in schools of culturallyresponsive leadership, teaching and learning practices, than has been done before" (Parata, 2013).

\section{REFERENCES}

Alton-Lee, A. (2003). Quality teacher for diverse students in schooling: Best evidence synthesis. Wellington, NZ: Ministry of Education.

Berryman, M. (2010). Transforming the identities of Māori students in New Zealand's schools: Where we have been, what we have learned and what the future can hold. Retrieved from: http:// tekotahitanga.tki.org.nz/Videos/Conference-20102/ Keynote-Address/Keynote-Part-3
Berryman, M., \& Glynn, T. (2004). Culturally responsive school and community partnerships to avoid suspension. In J. Wearmouth, C. Richardson \& T. Glynn (Eds.), Addressing pupils' behaviour: Responses at district schools and individual levels. London, UK: David Fulton Publishers.

Bishop, R. (1996). Collaborative research stories: Whakawhanaungatanga. Palmerston North, NZ: Dunmore Press.

Bishop, R. (2005). Freeing ourselves from neocolonial domination in research: A kaupapa Māori approach to creating knowledge. In N. K. Denzin \& Y.S. Lincoln (Eds.), The sage handbook of qualitative research (3 ${ }^{\text {rd }}$ ed.), (pp. 109-138). Thousand Oaks, CA: Sage.

Bishop, R. (2008). Te kotahitanga: Kaupapa Māori in mainstream classrooms. In N. K. Denzin, Y.S. Lincoln \& L.T. Smith (Eds.), Handbook of critical and indigenous methodologies (pp. 439-458). Thousand Oaks, CA: Sage.

Bishop, R., \& Berryman, M. (2009). The te kotahitanga effective teaching profile. Set: Research Information for Teachers, 1, 19-23.

Bishop, R., \& Berryman, M. (2012). Te Kotahitanga: Investigating the sustainability of the te kotahitanga professional development project. The National Institute for Research Excellence in Māori Development and Advancement, University of Auckland.

Bishop, R., Berryman, M., \& Richardson, C. (2001). Te toi huarewa: Effective teaching and learning strategies, effective teaching materials for improving the reading and writing in te reo Māori of students aged five to nine in Māori medium education. Hamilton, NZ: Ministry of Education.

Bishop, R., Berryman, M., Wearmouth, J., Peter, M., \& Clapham, S. (2011). Te kotahitanga; Improving the educational achievement of Māori students in English medium schools: Report for phase 3 and phase 4: 2008-2010. Wellington, NZ: Ministry of Education.

Bishop, R., Berryman, M., Tiakiwai, S., \& Richardson, C. (2003). Te kotahitanga: The experiences of year 9 and 10 Māori students in mainstream classrooms, Report to the Ministry of Education. Wellington, NZ: Ministry of Education.

Bishop, R., Berryman, M., Cavanagh. T., Teddy, L., Clapham, S., \& Walker, R. (2006). Te kotahitanga whanaungatanga: Addressing the problem of improving Māori student achievement. Paper presented at the New Zealand Association for Research in Education National Conference, Rotorua, New Zealand. 
Bishop, R., Berryman, M., Cavanagh, T., \& Teddy, L. (2007). Te kotahitanga phase 3 whanaungatanga: Establishing a culturally responsive pedagogy of relations in mainstream secondary school classrooms. Report to the Ministry of Education. Wellington, NZ: Ministry of Education.

Bishop, R., Berryman, M., Wearmouth, J.B., \& Peter, M. (2012). Developing an effective education reform model for indigenous and other minoritized students. School Effectiveness and School Improvement: An International Journal of Research, Policy and Practice, 23(1), 49-70.

Bishop, R., \& Glynn, T. (1999). Culture counts: Changing power relations in education. Palmerston North, NZ: Dunmore Press.

Bishop, R., \& Glynn, T. (2004). Achieving cultural integrity in education in Aotearoa/New Zealand. In J. Wearmouth, T. Glynn, R.C. Richmond \& M, Berryman (Eds.), Understanding Pupil Behaviour in School: A Diversity of Approaches (pp. 107 133). London, UK : David Fulton Publishers.

Gutschlag, A. (2007). Some implications of the te kotahitanga model of teacher positioning. New Zealand Journal of Teachers' Work, 4(1), 3-10.

Hawk, K., \& Hill, J. (2000). Towards making achieving cool: Achievement in multi-cultural high schools. Report to the Ministry of Education. Albany, NZ: Massey University.

Ladson-Billings, G. (1995). Toward a theory of culturally relevant pedagogy. American Educational Research Journal, 32(3), 465-491.

Lawrence, D. (2011). What can I do about Māori underachievement? Critical reflections from a nonMāori participant in te kotahitanga. set: Research Information for Teachers, 3, 32-38.

McLaren, P. (2003). Life in schools: An introduction to critical pedagogy in the foundations of education ( $4^{\text {th }}$ ed.). Boston, MA: Pearson Education.

McNaughton, S. (1995). Patterns of emergent literacy. Oxford, UK: Oxford University Press.

Meyer, L., Penetito, W., Hynds, A., Savage, C., Hindle, R., \& Sletter, C. (2010). Evaluation of te kotahitanga: 2004-2008: Summary report. Wellington, NZ: Jessie Hetherington Centre for Educational Research, Victoria University.

Ministry of Education (2011). Tātaiako: Cultural competencies for teachers of Māori learners. Wellington, NZ: Ministry of Education.

Parata, H. (2013). More than $\$ 31$ million allocated for building on success. Retrieved from http://www. waikato.ac.nz/news-events/media/2013/12more-than31-million-allocated-for-building-on-success.shtml
RTLB Toolkit. Retrieved from: file://C:/Users/ gprabhakar/Downloads/RTLB\%20Toolkit_ Professional\%20practice\%20 (7). pdf.

Sarra, C. (2011). Strong and smart: Towards pedagogy for emancipation: Education for first people. London, UK: Routledge.

Scheurich, J. J., \& Young, M.D. (1997). Coloring epistemologies: Are our research epistemologies racially biased? Educational Researcher, 26(4), 4-16.

Smith, G. H. (1992). Tane-nui-a-rangi's legacy... propping up the sky: Kaupapa Maori as resistance and intervention. Paper presented at the New Zealand Association for Research in Education/ Australian Association for Research in Education joint conference, Deakin University, Australia.

Smith, G. H. (1995). Whakaoho whānau: New formations of whānau as an innovative intervention into Māori cultural and educational crises. He Pūkenga Kōrero, 1(1).

Taffs, B. (2012). Embedding te kotahitanga reform. Retrieved from: http://www.educationalleaders. gov....ward-recipients-2012/Taffs-Bernard.

Vygotsky, L. S. (1978). Mind in society: The development of higher psychological processes. Cambridge, MA: Harvard University Press.

\section{AUTHOR PROFILE}

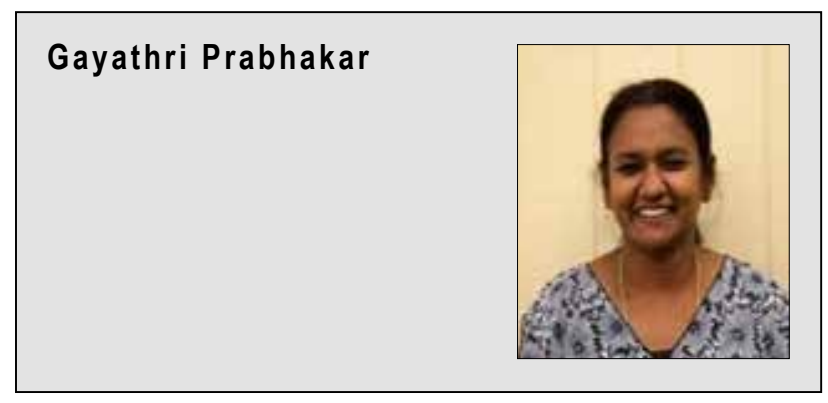

Gayathri Prabhakar Pillai is an RTLB from Cluster 9 in South Auckland. Prior to this, she worked as a Science/ Social Studies teacher at Kelston Girls' College for eight years, the last two of which was as SENCO. At KGC, she had the opportunity to complete the Te Kotahitanga Programme. She is currently completing a PG Diploma in Specialist Teaching (Learning \& Behaviour) and is of Indian descent. Her area of interest is inclusive education and culturally-responsive practice.

Email:

gpillaisoutherncross@gmail.com 